\title{
A Study on the Teaching of Business English Writing from the Perspective of Fuzzy Linguistics
}

\author{
Liu Yi \\ School of Foreign Studies Anhui Sanlian University \\ Hefei Anhui, 230601
}

\begin{abstract}
Fuzzy linguistics holds that language is uncertain. If business English writing excessively pursues accuracy, it can sometimes make literature lose its aesthetic sense, especially in business English writing. On the basis of fuzzy linguistic theory, it has become more and more urgent to reform the teaching mode of business English writing. Excessively pursuing accurary also restricts the cultivation of students' writing ability in business English, so it is necessary to introduce the case teaching method into business English writing teaching.
\end{abstract}

Keywords-Fuzzy linguistics; Business English Writing; Teaching Research

\section{INTRODUCTION}

In 1965, American cybernetics expert L. A. Zadeh put forward the famous fuzzy theory, which created a new scientific thinking method, and the subject of fuzzy linguistics came into being. In a broad sense, fuzzy language refers to the uncertainty, inaccuracy and ambiguity of the boundary of a word or concept. It's relative to certainty, accuracy, clarity. When people use language to express emotions, they sometimes need precision and clarity; more often they need ambiguity, because some things are themselves vague; moreover [1], In fact, the fuzziness of language does not affect the verbal communication and information exchange among people. On the contrary, it is the fuzziness that plays a positive role in verbal communication. Making speech more persuasive and contagious. In international business communication, the two sides establish long-term and effective trade relations for the smooth progress of friendly cooperation, the use of fuzzy language is essential. In business English correspondence, the correct and proper use of fuzzy language can make the language more polite, euphemistic, implicit, accurate and flexible. Fuzzy language plays an important role in business English writing.

Fuzzy linguistics holds that language has fuzziness, and the phonetic, semantic, lexical, syntactic and pragmatic aspects of the language are all vague. Pierce defines "vagueness" as "when there are several possible states of things that, despite careful reflection by the speaker, are practically uncertain." Vague language is not an ambiguous language, but an accurate expression of vague concepts. Wu Tieping believes that the accuracy and fuzziness of language can coexist in the same category of word meaning. The fuzziness of language is more obvious in literary works. The fuzziness of language makes literary works more attractive and enriches the artistic effect of language. The uncertainty of fuzzy language can realize the recreation of language. In poetry works, fuzzy language is often seen. It is the uncertainty of language that gives people the beauty of vagueness and makes readers think better.

\section{CHARACTERISTICS OF BUSINESS ENGLISH WRITING}

Business English is a branch of ESP, which has its unique requirements and characteristics. Because of the wide coverage of Business English writing, it covers business correspondence, memos, sales letters, etc., and each has its own characteristics. Therefore, according to the author's teaching practice, business English correspondence and telegram in foreign trade transactions are discussed.

The characteristics of business English correspondence and telegram are firstly reflected in the use of a large number of professional words [2], such as irrevocable and confirmed L / $\mathrm{C}$ (irrevocable and confirmed L / C) proforma invoice. The form and meaning of these professional words are relatively fixed and are often used as a word. Terms such as documentary collection (D / P) appear in payment letters, shipping instructions (bill of lading) and so on. Business letters. Again, some terms are expressed in the register of business English, such as under separate cover (cut the profit margin to the limit).

The main purpose of business correspondence is to exchange information, describe the characteristics of goods, or ask for business. Or urge the other party to react. To achieve the above purpose, the general use of declarative and imperative sentences. Secondly, the sentence is straightforward, simple grammar, rarely use rhetorical devices. In the "time is money" business environment, Business English correspondence and telegram has formed a concise stylistic feature with clear purpose and clear expression, avoiding rhetoric as far as possible, so as to avoid ambiguity and save both sides' time. Business English correspondence and telegram often use relatively fixed sentence patterns.

The text structure of business English correspondence and telegram is short and short, and the internal structure is relatively fixed, and the logic is tight and the meaning is close. A business letter consists of a letter header, date, address, text, closing honorific, and sometimes a number, title, etc. The main body of the message is the body of the message, including the opening sentence, the text and the ending sentence. Each part has a function: the chapeau often refers to the previous letter, or to gratitude or regret, or to a straightforward presentation of the main thrust of this letter; the text deals with business, using a single paragraph when it is simpler, and setting up multiple 
paragraphs when more, A topic in each paragraph; the closing sentence offers hope or wishes. For example, the opening sentence of the offer expresses thanks for the other party's inquiry, or informs us of the general information of the existing goods; the text puts forward the terms of the transaction, the term of validity of the offer and the constraint conditions; the closing sentence is often a promotional sentence to encourage the other party to place an early order.

\section{The MaIn Problems IN The TEACHING OF BUSINESS ENGLISH WRITING}

At present, one of the main problems in the teaching of business English writing is that the traditional writing teaching methods and models are still adopted, so that the current teaching does not coincide with the actual needs of the students in business work. It can not meet the requirements of compound talents training, which is reflected in the current teaching materials and teaching methods.

Throughout the existing business English writing textbooks, there are three shortcomings: first, the coverage of the subject is very narrow, most of them are still confined to the writing of business letters or telegrams, and the second is that the content is not comprehensive. Focus on teaching all kinds of business writing methods and skills, [3]ignoring the introduction of relevant business knowledge, but in fact, many business styles, such as sales contracts and business plans and other writing and international trade, marketing and other knowledge has a close relationship; The third is that the writing mode is aging, most of them are compiled according to the model of English model and Chinese translation, and there is a big gap between the teaching material and the rapid development of economy.

Business English writing is based on ordinary English writing, but can't carry on the teaching mode of ordinary English writing in the classroom. However, the current business English writing teaching usually adopts the traditional English writing teaching method, which can not reflect the characteristics and requirements of the business English writing course. It can not arouse the students ' interest and motivation.

The teacher's knowledge structure is not perfect, and the students' basic knowledge is not solid enough. At present, most business English teachers have only English major background and lack business knowledge and practice seriously. As a result, the teaching of business English writing is out of touch with the reality of business activities, and the contents are empty and lack of pertinence, and the students also lack the experience of business practice. There is also no opportunity to explore business knowledge or collect information through field surveys, resulting in students simply unable to complete writing in more complex business styles such as business plans, business contracts, and so on.

In recent years, case teaching has been widely used in the teaching of trade, management, marketing and other courses, and has achieved good results. The author suggests that the case-based approach should be applied to the classroom teaching of business English writing [4]. Through the introduction of a large number of relevant business knowledge through specific cases in the teaching, the business writing is closely combined with the specific business situation to help the students understand the background of the formation of the model essay and the application of a specific style in the actual business activities. In order to help students overcome the lack of business knowledge caused by writing Make difficulties.

Case teaching method means that on the basis of students' mastering basic knowledge, basic skills and operation theory, teachers use typical cases according to the requirements of teaching purpose and teaching content. The teaching method of guiding students to use the knowledge they have learned to think and analyze the specific problems and finally solve the practical problems. Obviously, the case teaching method embodies three levels of thinking: first, student-centered, disquisition-based, the aim is to develop students' ability to analyze and solve problems; second, to encourage students to study independently and innovatively; and third, the ultimate goal is not to provide students with fixed principles, axioms and laws. In a word, its core idea is that students are the center and the main body of teaching, and the active participation of students is the key of teaching.

In recent years, the focus of teaching has gradually shifted to student-centered, encouraging students to carry out independent innovation learning, and the use of case teaching method can meet the needs of the shift of emphasis and independent innovation learning. First of all, it is good for students to discover learning. The implementation process of the case teaching method is: the teacher puts forward the casedetermines the central problem, then the student discovers the problem-analyzes the problem-solves the problem. This teaching mode of learning in active inquiry is conducive to improving students' interest in learning and fully arousing students' enthusiasm and initiative, at the same time, it is conducive to cultivating students' ability of independent thinking and independent innovation. Secondly, it is helpful for teachers to conduct guided teaching. If students have an interest in learning, they will undoubtedly actively participate in the teaching process closely following the teaching progress of the course, and under the guidance of the teachers, they will make comprehensive use of their own economic and trade knowledge and English ability to analyze and discuss cases. So as to train students' ability to solve practical problems. Finally, it is helpful for students to combine theory with practice. A prominent feature of the case approach is to give students a sense of reality, because most of the case materials come from problems that are often encountered in actual business activities. This makes the knowledge in the book closer to the students. Under the guidance of the teacher, the students can solve the practical problems with the knowledge they have learned, so that the students can really connect theory with practice.

No matter what kind of teaching mode, generally can not leave several most basic teaching implementation link, the case teaching method is no exception, only effectively implements these basic teaching links, can guarantee the entire case teaching method's success. Generally speaking, the case teaching method has the following four basic links: the case preparation and design, the case analysis and discussion, the case summary and the practice, the case mutual comment and the appraisal. 


\section{The APPlication of CASE TEACHING METHOd IN BUSINESS ENGLISH WRITING TEACHING}

The course of business English writing has three teaching characteristics: real corpus, purpose-oriented and autonomous learning. Therefore, in teaching practice, teachers should organize classroom teaching with case as the center. Taking the basic content of the case as the basis of discussion, the students are required to make use of the knowledge of economy and trade and English skills to study independently and innovatively in the case analysis and discussion around the specific purpose of writing.

The teaching function of the auxiliary business English writing teaching system is very strong, the information automation degree is high , the capacity of the commercial special corpus is large, the server on the center is shown in the figure, the teacher and the student are connected with the writing teaching system of the center through the network, the function integration of the network teaching, the machine auxiliary writing, the automatic evaluation and the writing demonstration research is realized, and the complete business English writing teaching solution is a complete set of business English writing teaching .

Taking business correspondence writing and computeraided practice as an example, the whole teaching process can be summed up into three stages and three forms. The three stages are 1 inorganic auxiliary writing and 2 half computer assisted writing. In the first stage, the teacher focuses on the basic knowledge and skills of business correspondence writing in this unit, and arranges a number of business correspondence writing exercises without any computer-assisted writing functions open to students. Ask students to write independently on a computer in an inorganic state, practice the language, format, and writing skills of business correspondence, upload the assignment to the teacher or assistant and comment on it in the second stage. Part of the lexicon, phrase library, dictionary database such as CET-4, CET-6 and CET-4, CET-8, CET-4, CET-8, error-prone vocabulary, business English dictionary, etc. To arrange a number of business correspondence writing exercises to enable students to be assisted in part by a systematic corpus when writing, and to further familiarize and master the characteristics of business correspondence writing with the help of professional vocabulary and phrase auxiliary writing functions. After completion, the teacher can use the automatic scoring system to correct and comment on the composition. In the third stage, the students have become familiar with and master the main functions of computerassisted writing, and the teacher can open up the writing sentence base and paragraph database to the students. The text library or fan library and other related functions arrange a number of difficult business correspondence writing tasks so that students can improve fluency and correctness with the help of computer-assisted writing. To achieve proficiency in computer-assisted writing and business correspondence writing skills, teachers can automatically score and feedback on students' homework. There should be three forms of online writing in each stage. Students should complete their writing tasks according to the teacher's needs and time. And submitted to the teacher evaluation 2 teachers select key comments or online individual feedback 3 students extracurricular writing exercises and computer-assisted self evaluation. The above teaching mode realizes man-machine interaction, cooperation between teaching and learning, effectively breaks through the limitation of class size of writing class, makes up for the poor operation of class, insufficient intensity of exercise, large amount of composition evaluation and inconsistent standards. Business professional knowledge is not comprehensive, writing empirical research is difficult to carry out bottlenecks.

The key to the preparation and design of cases and case teaching methods is to design reasonable and operable cases, and the following conditions must be met: first, the requirements of the content, the case must reflect the actual needs of business activities and the characteristics of various business styles, At the same time, we should try our best to combine the teaching content of business English writing course with the relevant business knowledge, so as to provide realistic situations for students to simulate the actual business activities. So as to help students to understand and understand the specific use of a certain style in actual business activities. Second, the requirements of the hierarchy. General cases should include two levels: the first level is a large number of small cases, the second level is the key case which is combined with business practice. Because the main body of business English writing teaching is to analyze, discuss and train the key cases. So the second level of cases should be the focus of teaching. Third, the requirements of collection and compilation. The collection and arrangement of cases should be based on the business investigation and literature collection, based on rich practical data, carefully selected. Each case should include a background description, student task, questions discussed in the classroom and writing practice in combination with the case [5]. The other cases should be written in English as far as possible. In order to facilitate teachers and students to use English communication in teaching, and finally lay a solid foundation for students to use their economic and trade knowledge and English for business writing.

Since the beginning of the year, the Ministry of Education has clearly proposed in the revised requirements for College English Teaching that the application of computers in college English teaching should be strengthened, and a model of college English teaching based on classroom and computer should be established. Many universities throughout the country have participated in the reform. Many colleges and universities have become the model of reform. By the year, the reform of multimedia network foreign language teaching has made remarkable achievements, the computer-assisted college English teaching model has been established, and the popularization of computer multimedia classrooms and campus networks has been basically realized in colleges and universities throughout the country. Multimedia courses and courseware are widely used in all kinds of listening and speaking courses, and the Committee has also taken the lead in introducing the "Computer-Assisted Translation Teaching system" and the course Wang Li. At the same time, computerassisted foreign language testing has developed rapidly and all kinds of foreign language computer tests have been developed. In addition, the training and popularization of computer-aided language research methods have been used by many foreign language teachers to master and apply Wang Li. Wang Jin-ru. 
Computer assisted Foreign language Teaching and Research is very active, Beijing Foreign Studies University Network College, China Foreign language Education Research Center, The Foreign language Teaching and Research Publishing House has organized several academic conferences on "the Application of computer Network in Foreign language Teaching". Since the beginning of the year, the editorial Office of Shanghai Foreign Studies University, "Audio-visual Teaching of Foreign languages", Shanghai foreign language audiovisual publishing house has jointly sponsored the "academic seminar on the integration of internet information technology and foreign language curriculum". The china foreign language education research center organizes "the application of computer in foreign language teaching and research" in china high school every year. Advanced course for Foreign language teacher Development.

The research on computer-assisted English writing teaching has received extensive attention in foreign countries. It has been found that Wikimedia based English writing is helpful to college students' writing ideas. Research on computer Writing Teaching Software Yang Yonglin and others have found that computer writing training can promote the improvement of foreign language proficiency. Graduate students are generally interested in learning applied writing software, reflecting their ability to help clarify ideas, put forward ideas, build frameworks, and plan the layout of articles, etc. Both international and domestic second language writing studies have focused on the teaching of writing and the application of computer-assisted techniques. Wang $\mathrm{Li}$ is concerned with the development of writing theory. The western writing teaching theory has experienced a developing process from "writing result theory" to "writing process theory" to "metacognition theory" and "social cognition theory". It is emphasized that the teaching of writing should be assisted by teachers, teaching materials and model articles, and the task of writing should be decomposed in stages, and students should be gradually separated from the support of "scaffolding" to achieve independent writing. The "genre" theory is based on the theory of functional linguistics. Emphasis on the role of contextual knowledge and the three essentials of writing field, tenor and style. The difference between oral language and written language determines the mood and attitude of writing. The social cognitive theory puts forward the social cognitive model of writing teaching, and determines the author in writing. The dynamic interaction among the subjects and readers regards the writing process as a cyclic nonlinear process and persuasion. The above writing theories and principles can be realized by computer information technology in the computer network environment. Suggestions for Computer-Assisted English Writing Teaching It provides a reliable theoretical basis and a broad space for development. However, the research and software development devoted to the integration of English writing and computer technology in China is relatively weak in recent years. There are only a few computer writing teaching systems or writing automatic scoring software in the market. Some of them are too simple to design and teaching ideas are not advanced enough. Some writing automatic scoring software can only be used independently. The whole process of writing teaching and scientific research can not be effectively combined, and the software is not supported by large special corpus. The advantages of computer-aided writing teaching system are far from being fully realized.

For a long time, the teacher's biggest worry about the writing course is that the workload of correcting the composition is too great. Each student has to write more than one composition in a semester. If the students are not seriously corrected, the students' writing will not be effectively directed, and the teaching effect will be affected. The function of computer-aided composition correction solves this problem which has been puzzling the writing teachers for a long time. The system includes scores of scores provided by writing experts, including language grammar, text structure, subject content, format and so on. According to the teacher's request, the machine gives each score and total score after the automatic evaluation of the composition, and provides the reference comment. Teachers can check the reliability and validity of the evaluation, modify the results and comments, or use the evaluation template to check or add the comments, so that the system can automatically remember.

We can carry out multi-dimensional empirical research from two aspects of writing output and error analysis. Using corpus, we can compare large samples from different angles and dimensions, and can also annotate different types of writing corpus. For example, part of speech encode, semantic code, syntactic tagging, etc. It broadens the perspective and approaches of the study of second language writing from the point of view of research method. 1 contrast native language writing corpus with second language writing corpus 2 contrast second language writing corpus with different mother tongue background 3 contrast different levels of students' composition 4 contrast oral language. The above comparative study can find the rules and characteristics of students' writing ability development. To find out the commonness, characteristics and error characteristics of writing ability acquisition, to provide the basis for effective writing teaching.

It is an innovation of this system to use the students' composition data to carry out an empirical study on writing, to investigate the development law and characteristics of the students' written interlanguage) whether it is to collect a student's multiple compositions. It is also very convenient to collect the composition data of the whole class or grade students and use the writing research function of this system. Independent of subjective judgment, the scientific and reliability of the research is increased by using a large number of real works. The sample data can avoid the limitation that only depends on individual and sporadic examples to draw conclusions. A large amount of valuable composition data can be saved copied and retrieved for a long time which provides the possibility for confirmatory research. 


\section{CONCLUSION}

In a word, the cultivation and improvement of English writing ability is not a matter of the day. We should persevere, step by step, listen, speak, read and write together, pay attention to accumulation, master skills, train more, and teachers should give scientific guidance. From the first to the third grade teaching, strict requirements, step by step learning and training, can achieve good results. Computer-assisted business English writing has a broad application prospect and should be attached great importance to as a developing direction of the teaching reform of business writing in colleges and universities. The new round of English teaching reform should realize four changes: 1 . The emphasis on language skills should be changed from language skills to language skills as well as professional content. Combining listening, speaking, reading and writing skills with relevant professional knowledge. 2. Shift from inputting-led language skills teaching to highlevel language skills combining output and content, opening speeches, business writing, interpretation and translation, business negotiation, etcCheng. 3 changes from traditional multimedia to computer-aided mode, building a large corpus, using multi-modal, automatic speech recognition, translation memory and machine automatic scoring techniques to build a computer-assisted foreign language teaching platform. A new generation of computer-assisted foreign language teaching software has been developed.

\section{ACKNOWLEDGMENT}

This thesis is the stage research results of Provincial Teaching and Research Projects--A Study of Business English Writing Teaching in Applied Undergraduate Colleges from the Perspective of Fuzzy Linguistics (2015jyxm412), Provincial Major Teaching and Research projects--A Study on the Innovation of College English Curriculum System and Talent training Model in the Transformation Period of Colleges and Universities (2016jyxm0341) and Famous Master Atelier (2016msgzs028).

\section{REFERENCES}

[1] A contrastive study of Cai Jigang's English-Chinese writing [M] .Shanghai: Fudan University Press, 2003

[2] Carter, D. Some propositions about ESP [J].The ESP Journal, 1983, (2):131-137.

[3] Cheng Xiaotang, English learning strategy [M] .Beijing: foreign language Teaching and Research Press

[4] Wu Tieping. Vague language Literature [M] .Shanghai: Shanghai Foreign language Education Press, 1999: 67-78.

[5] Peng Yanling. The Application of case Teaching method in Business English Writing Teaching $[\mathrm{J}]$.Journal of Yunnan University of Finance and Economics: 1: 141-142. 